\title{
Breeding Biology, Chronology, and Reproductive Success of the European Serin (Serinus serinus) at Moulouya High Plain (Morocco)
}

\author{
Ismail Mansouri (D), ${ }^{1}$ Wafae Squalli $\left(\mathbb{D},{ }^{1}\right.$ Mohamed Dakki $\left(\mathbb{D},{ }^{2}\right.$ Amine Assouguem (D), \\ Abdelbari El Agy (D), ${ }^{1}$ Abderahim El Hassani ${ }^{D}$, ${ }^{1}$ Chaimae Belarbi, ${ }^{1}$ Youssef Dbiba, ${ }^{3}$ \\ Hassnae Kouali ${ }^{\mathbb{D}},{ }^{4}$ and Lahsen El Ghadraoui ${ }^{1}$ \\ ${ }^{1}$ Laboratory of Functional Ecology and Genie of Environment, Faculty of Sciences and Technology, \\ Sidi Mohamed Ben Abdellah University, Fez, Morocco \\ ${ }^{2}$ Laboratory of Go-Biodiversity and Naturel Patrimony, Scientific Institute, Mohammed V University, Av. Ibn Battota, 10 BP 703, \\ Rabat, Morocco \\ ${ }^{3}$ Laboratory of Water, Biodiversity and Climate Change, Faculty of Science, Cadi Ayyad University, Marrakech, Morocco \\ ${ }^{4}$ Environnement \& Health Research Team, Department of Biology Polydisciplinaire Faculty, Cadi Ayyad University, \\ Marrakech, Morocco
}

Correspondence should be addressed to Ismail Mansouri; mankhori@gmail.com

Received 9 April 2021; Revised 12 June 2021; Accepted 30 June 2021; Published 8 July 2021

Academic Editor: Marco Cucco

Copyright (c) 2021 Ismail Mansouri et al. This is an open access article distributed under the Creative Commons Attribution License, which permits unrestricted use, distribution, and reproduction in any medium, provided the original work is properly cited.

\begin{abstract}
The European serin (Serinus serinus) is one of the best examples of a species in the western Palaearctic that has expanded its distribution ranges in current periods. However, the breeding features of serin are not well known and were restricted for some localities, as well as there have not been any deep and comparable studies on its mortality and menacing factors. This study investigates breeding biology, including breeding chronology, nesting strategies, and reproductive success of the European serin in farmland and woodland habitats at Moulouya high plain (Morocco), during 2016. Results showed that, at high-altitude breeding habitats, the European serin started breeding activity lately by 25 April (construction of the first nest) and continued until 19 July (last fledging date). Moreover, most nests (96.42\%) were found in farmlands, mainly in apple orchards. Two broods were recorded between April-May and June-July, and the clutch size was an average of $3.04 \pm 0.13$ eggs/nest. For reproductive success, among the 65 examined nests, $73.84 \%$ were active during the nest construction phase and $87.42 \%$ of eggs have succeeded during the incubation phase. Reproductive success was higher (93.83\%) during fledging. Clutches were failed due to predation (15.9\%), nest desertion (14.35\%), and destruction of nests (8.88\%). Finally, our study highlights that the European serin breeds in highaltitude zones with late and shorter breeding seasons, which might allow this bird to avoid high lands' vigorous climate conditions and their effect on breeding success.
\end{abstract}

\section{Introduction}

Information on breeding biology and reproductive performances of avian species constitutes a central part in the understanding of their population bio-ecology and adaptation, as it permits the academics and wild defenders to identify problems $[1,2]$. Equally, it has direct implications in conservation procedures [3]. On the other hand, the study of breeding biology allows to estimate breeding success and productivity, which are likely useful in population dynamics.

The serin (Serinus serinus) is a small, socially monogamous finch $[4,5]$, common in southern Europe, North Africa, and some western parts of Asia, which sings intensively throughout the breeding period. The serin is one of 
the best examples of a species in the western Palaearctic that has expanded its distribution ranges in recent times [6]. The breeding biology, chronology, and success of the serin are not well known and were limited for some localities, and there have not been any comparable studies on its mortality and failure factors mainly in the south of the Mediterranean Basin [7].

In North Africa, the European serin is reported as resident and breeding species [8]. In Algeria, the species is well studied in terms of distribution ranges, habitat use, and breeding seasons [8-10]. While in Morocco, the bird is less studied, and most observations were fragmented in time and space $[11,12]$. However, with the recent changes in climatic conditions, intensification of agricultural activities, and illegal capture and trade of wildlife species $[13,14]$, the knowledge of the features that could impact the breeding performance and survival of this small Fringillidae is urgently required.

In this study, we used field prospects to uncover breeding performances of the European serin in different ecosystems. We analysed the patterns of breeding biology, breeding chronology, and nesting strategies inside farmlands and woodlands. More specifically, we studied nesting trees, nest location, breeding chronology (nest construction dates, laying dates, and hatching dates), and breeding success in orchards and woody vegetation. These aspects are suggested to fill the gap of lacking data about this tiny bird in Morocco and North Africa.

\section{Materials and Methods}

2.1. Study Area. Fieldwork was conducted in the northwest Moulouya high plain, situated at Midelt Province, DaraaTafilalet region, between the High Atlas mountains in the North and Middle Atlas in the Northeast (Figure 1). Geographically, the study zone was at a high altitude ranging between 1300 and $1600 \mathrm{~m}$ upon sea level [13]. The Moulouya zone is characterized by a cold arid climate with a mountainous tendency, and the rainfall regime is marked by a variable and irregular low rainfall; stormy precipitation brings eroded products upstream, the annual average temperature and precipitations being about $29^{\circ} \mathrm{C}$ and $89 \mathrm{~mm}$ successively. Two sites were selected: farmlands including 16 apple orchards and woodlands counting riparian habitats and forest plantation (small islets' vegetation around agricultural areas) (Table 1).

2.2. Data Collection. Based on results mentioned in [9] and preliminary field prospections during 2015, we searched for nests from early March to late August 2016 by means of parental behavioral cues (mainly, the courtship of the mating birds) and Common Birds Census (CBC) methodology [15], based on both the acoustic calls and the observation of birds during the breeding season. Inside farmlands, nests or breeding pairs were researched line by line based on apple orchards' tree-lines [12, 15] (Figure 2). In woodlands, nests and breeding birds were searched with a walked transect of five (two to three transects for visit in Tamarix, poplar and wild rose due to their small surfaces) to seven $\mathrm{km}(\sim 9$ transects for visit in Salix dominating the area), from 06.00 to 18.00 hours, based on the surface of each habitat.

We recorded the nest placement (five descriptors: nest height above the ground, nest distance to the central trunk, nest inside or in the periphery of orchard, and nesting-tree) and nest dimension (three descriptors: big diameter, small diameter, and depth). Similarly, breeding chronology (three descriptors: nest construction date (initiation of the first nest per season), laying date of the first egg, and hatching date of the first chick per season), nest status (three descriptors: new-empty, egg incubation, hatching and chick rearing), and failure factors (four descriptors: predation, desertion, destruction (natural and/or human impacts), or death of the clutch) were recorded. However, for nests discovered during the incubation or chick rearing stages, laying date could not be determined with precision. We thus relied on the aspect of eggs or chicks (feathers of nestlings), and we used descriptive accounts from known-aged nests in the same population and area to determine the nest laying date approximately. Similarly, the nature of predators was searched via shell, meat fragments, feathers, fresh animals, and human traces inside or in the vicinity of nests. For example, rats typically leave eggshell fragments, while snakes feed on nests without leaving a trace [16]. To reduce the impact of our investigations on the monitored nests, we used an endoscopic camera to check nest contents, and measurements (nest dimensions) were realised via vernier calipers, during the morning when birds look for food out of the nest. In parallel, climatic conditions (diurnal temperatures and rainfall) were accessed from the Midelt Weather Station during 2016, to assess their impact on breeding chronology.

\subsection{Statistics. Statistics were done in STATGRAPHICS} Centurion software, version XVI.I, and results were given as sample size and mean \pm SD. Moreover, breeding success rates were evaluated by the calculation of success nests (active nests/built nests), hatching eggs (hatched eggs/laid eggs), survived chicks (chicks leaving their nests/fledged chicks) [15-17]. Clutch size was calculated as the number of eggs/total active nests. Preferences toward nesting trees were calculated by percentage (number of nest per supporting tree/all nests).

We checked for normality and homogeneity of variance for all variables via Kolmogorov-Smirnov test. Correlations among breeding chronology parameters (nest construction period (from first nest to the last nest), laying period (from first egg to the last egg), and hatching period (from first chick to the last chick) were tested with Pearson correlation coefficient. To assess differences in breeding success among breeding phases (nest construction, laying, hatching) and among failure factors (predation, desertion, destruction), the ANOVA One way test was used, considering the 16 breeding habitats inside farmlands (for breeding success). We analysed separately the relationship between breeding chronology (depending variables), including nest construction period, laying period, hatching period, temperature, and rainfall (factors) by General linear Model, and all variables with $P$ 


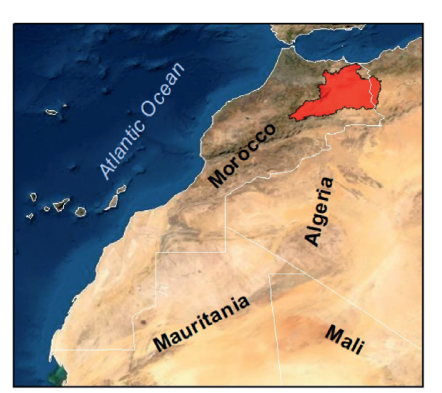

$5^{\circ} 15^{\prime} 0^{\prime \prime} \mathrm{W} \quad 5^{\circ} 10^{\prime} 0^{\prime \prime} \mathrm{W} \quad 5^{\circ} 5^{\prime} 0^{\prime \prime} \mathrm{W} \quad 5^{\circ} 0^{\prime} 0^{\prime \prime} \mathrm{W} \quad 4^{\circ} 55^{\prime} 0^{\prime \prime} \mathrm{W} \quad 4^{\circ} 50^{\prime} 0^{\prime \prime} \mathrm{W} \quad 4^{\circ} 45^{\prime} 0^{\prime \prime} \mathrm{W} \quad 4^{\circ} 40^{\prime} 0^{\prime \prime} \mathrm{W}$
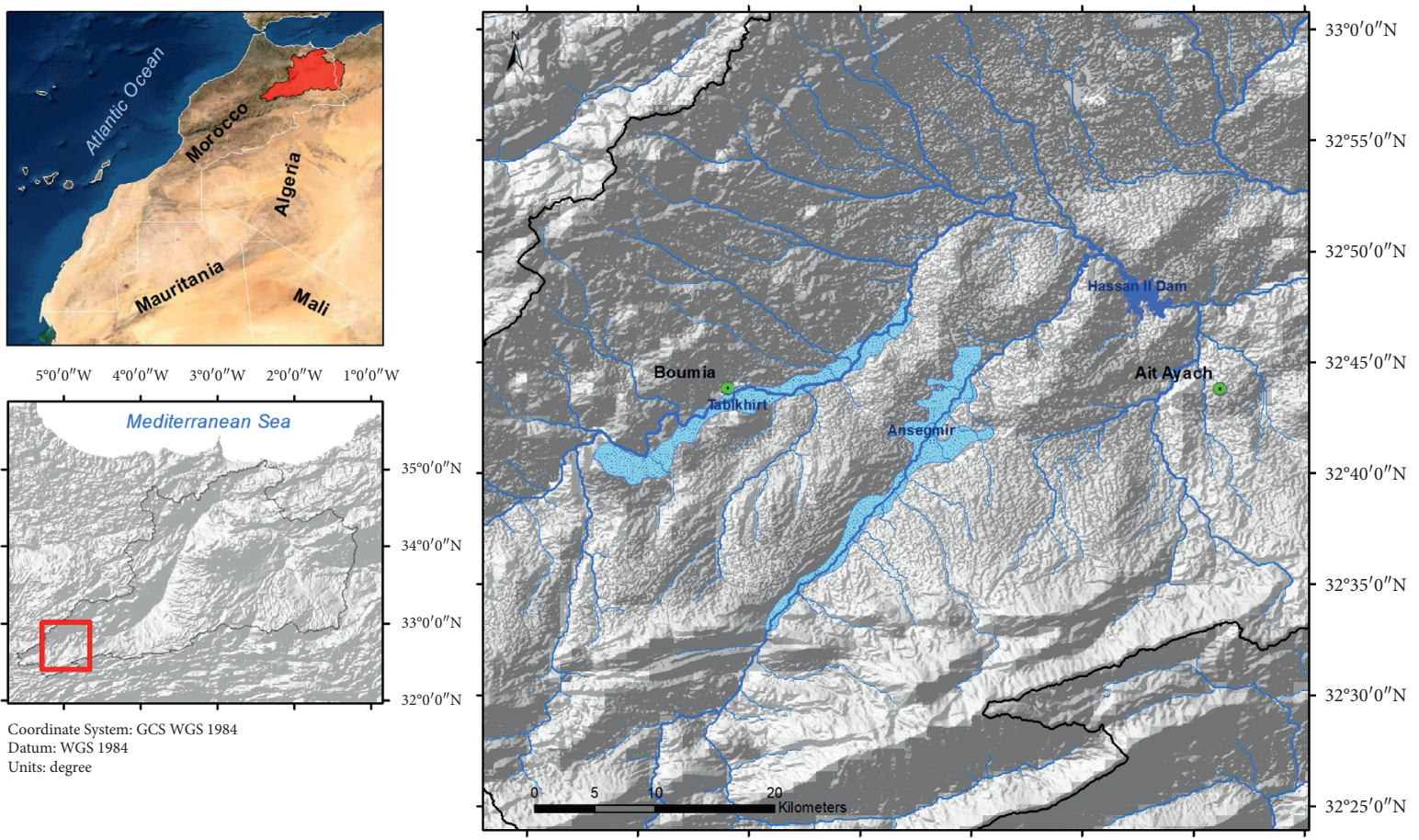

Floodplain

Hassan II dam

Moulouya watershed

FIgURE 1: Localization of Moulouya high plain in Morocco.

TABle 1: Principal agricultural lands and woody vegetation monitored at Moulouya high plain.

\begin{tabular}{lccc}
\hline Habitat & Type & Vegetation & Surfaces (Ha) \\
\hline \multirow{3}{*}{ Woodland } & & Salix & 330 \\
& Riparian & Tamarix & 15 \\
& & Poplar & 8 \\
& Forest & Wild rose & 14 \\
\hline Farmland & Orchards & Apple trees & 3.5 \\
\hline
\end{tabular}

values lesser than 0.5 were considered as predicting factors. To investigate the relevance of failure factors to impact the breeding success of the serin, during breeding phases, predation, desertion, destruction, death and unhatched nests were considered as predictors of success (response variables: with 0 (no fledglings produced for nest, no hatching of eggs, no occupation of nest) and 1 (at least one fledgling produced for nest, at least one egg has hatched and at least the nest was occupied for once), then a model with a binomial error structure and log it link function was applied.

\section{Results}

3.1. Nesting Strategies. At the end of the breeding season, $96.42 \%$ of nests $(n=54)$ were recorded on orchards (50\% on Golden delicious ( $n=28$ nests) and $46.42 \%$ Starkrimson delicious $(n=26$ nests $)$ ) and $3.52 \%$ woodlands $(1.78 \%$ on poplar and $1.78 \%$ on wild rose) (Figure 3(a)). Moreover, in apple orchards, $81.35 \%$ of nests were located in the center of groves, while only $18.64 \%$ of nests were located in the periphery ( $n=16$ orchards, $t=2.75357 P$

value $=0.013)$ (Figure 3(b)).

Generally, the Serin's nests were cup-shaped, with an external diameter of $8.30 \pm 0.29 \mathrm{~cm}(n=65$ nests), an internal diameter of $7.03 \pm 0.29 \mathrm{~cm}$, and a cup depth of $5.82 \pm 0.35 \mathrm{~cm}$. Nest height above the ground was $214.15 \pm 0.09 \mathrm{~cm}$ and $95.4 \pm 0.09 \mathrm{~cm}(n=65$ nests) far from the tree center trunk.

3.2. Breeding Chronology. The breeding chronology of the European serin, including nesting, laying, and hatching dates at Moulouya, is summarized in Figure 4. After the formation of breeding pairs (based on acoustic courtship and visual mating), initiation of nest construction began during the last week of April at Midelt (the first nest was recorded on 25 April), and the nesting period dated from 25 April to 5 July (last new-built nest of the season). In parallel, laying activity was observed on 28 April (the first egg), only three days after the construction of the first nest. The last laying date was on 15 July and the laying period was 78 days. On the other hand, the first observed chick was on 9 May, and eggs' hatching continues to 19 July. High correlations were revealed among breeding periods (Table 2). However, breeding periods were note influenced by temperatures and rainfall (Table 3). At the end of breeding season, two broods were observed; the first between April and May, and the second between June and July. 

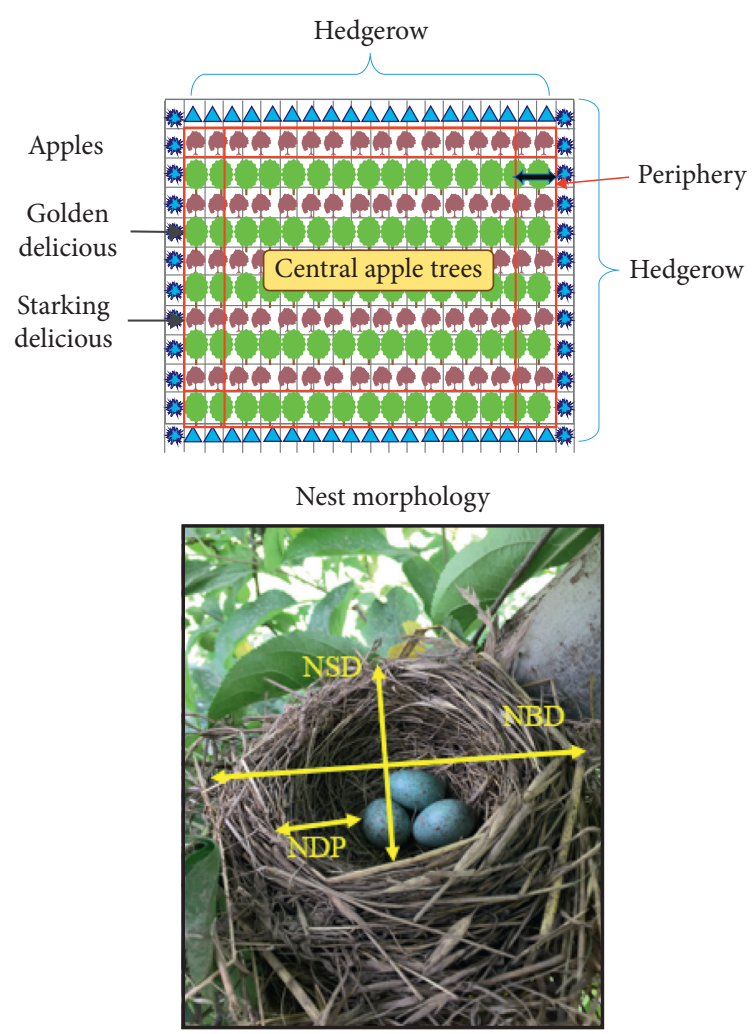

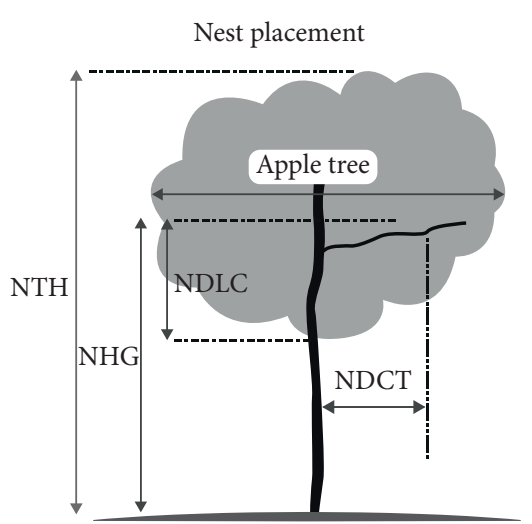

Nesting parameters

NTH: nesting-tree height

NHG: nest height above the ground

NDLC: lower canopy distance

NDCT: distance of nest to tree center

NBD: nest big diameter

NSD: nest small diameter

NDP: nest cup depth

Figure 2: Studied parameters, nesting sites, nest placement and morphology of the European serin in Moulouya.

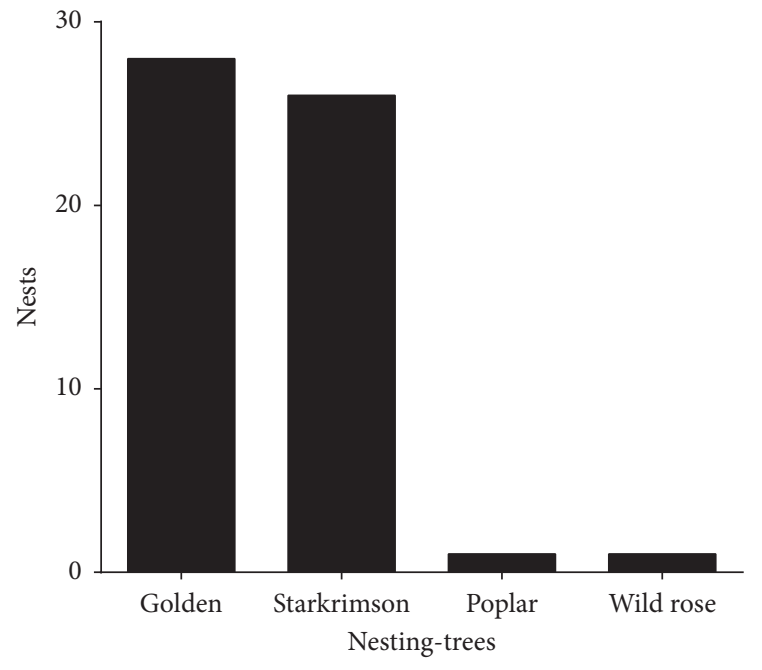

(a)

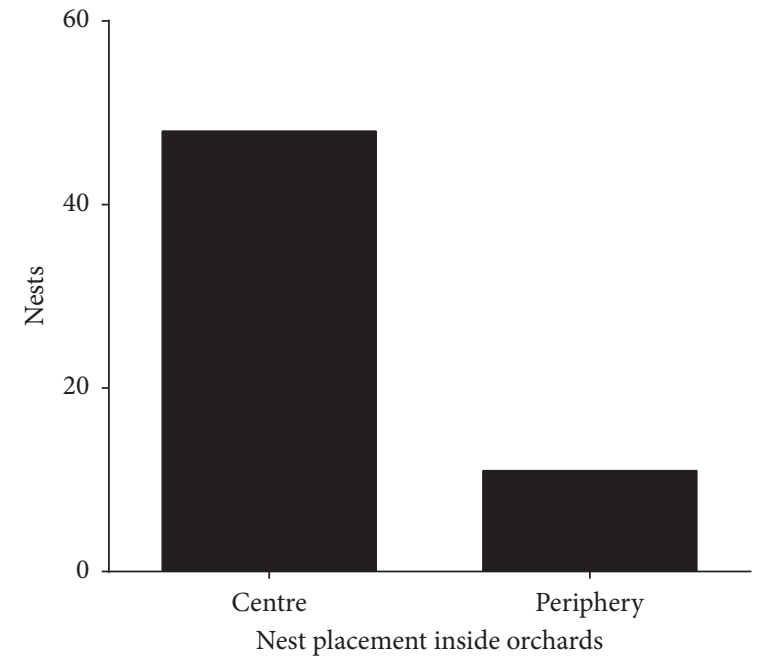

(b)

Figure 3: (a) Nesting-tree and (b) nest placement of European serin at Moulouya high plain.

3.3. Clutch Size and Breeding Success. In summary, the European serin's clutch size ranged between three and five eggs with a medium size of $3.04 \pm 0.13$ eggs. On the other hand, among the 65 recorded nests (Table 4), 73.84\% were succeeded (were active during all breeding phases) at Moulouya high plain. During the incubation period, the fledging success rate was more significant, with $87.42 \%$ hatched eggs. Equally, during the rearing phase, $93.83 \%$ of chicks have survived. In total, success rates were higher during chicks rearing $(n=15$, $F=699.14, \mathrm{Df}=2, P<0.001$ ) (Figure 5).

Failure factors were variable (Table 5). In summary, $15.9 \%$ of clutches were failed due to predation attacks ( $7.69 \%$ of nests, $4.79 \%$ of eggs, $3.42 \%$ of chicks), $14.35 \%$ of clutches were failed due to nest desertion by parents (10.76\% of nests, $3.59 \%$ of eggs) and $8.88 \%$ of clutch due to destruction of nests $(7.69 \%$ of nests, $1.19 \%$ of eggs) ( $n=15$ orchards, $F=1.08, \mathrm{Df}=2, P=0.349$ ). 


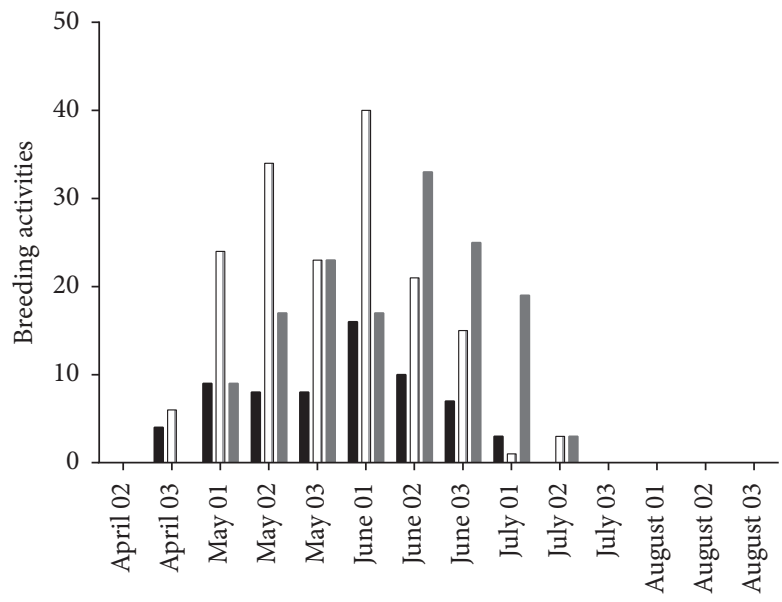

Dates (10 days)

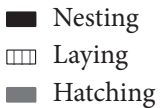

Figure 4: Breeding chronology of the European serin at Moulouya high plain.

TABle 2: Pearson correlation coefficients among breeding periods of the European serin at Moulouya high plain.

\begin{tabular}{lccc}
\hline & Hatching (chicks) & Laying (eggs) & Nesting (nests) \\
\hline Hatching (chicks) & - & 0.7004 & 0.7494 \\
$P$ value & - & 0.0116 & 0.0069 \\
Laying (eggs) & 0.7004 & - & 0.9299 \\
$P$ value & 0.0116 & - & 0.0008 \\
Nesting (nests) & 0.7494 & 0.9299 & - \\
$P$ value & 0.0069 & 0.0008 & - \\
\hline
\end{tabular}

TABLE 3: Relationship between breeding periods and climatic variables (rainfall and temperatures) analysed via General linear Model.

\begin{tabular}{|c|c|c|c|c|c|c|}
\hline Periods & Factors & Sum of squares & Df & Mean square & F-ratio & $P$ value \\
\hline \multirow{4}{*}{ Nest construction } & Rainfall & 64.0168 & 1 & 64.0168 & 2.92 & 0.1157 \\
\hline & Temperature & 16.456 & 1 & 16.456 & 0.75 & 0.4051 \\
\hline & Residual & 241.441 & 11 & 21.9492 & & \\
\hline & Total (corrected) & 337.214 & 13 & & & \\
\hline \multirow{4}{*}{ Laying periods } & Rainfall & 104.636 & 1 & 104.636 & 0.55 & 0.4756 \\
\hline & Temperature & 0.713529 & 1 & 0.713529 & 0 & 0.9525 \\
\hline & Residual & 2109.98 & 11 & 191.816 & & \\
\hline & Total (corrected) & 2580.93 & 13 & & & \\
\hline \multirow{4}{*}{ Hatching periods } & Rainfall & 246.61 & 1 & 246.61 & 1.81 & 0.2054 \\
\hline & Temperature & 152.906 & 1 & 152.906 & 1.12 & 0.3119 \\
\hline & Residual & 1497.31 & 11 & 136.119 & & \\
\hline & Total (corrected) & 1749.43 & 13 & & & \\
\hline
\end{tabular}

\section{Discussion}

The study highlights the European Serin's reproductive biology at Moulouya high plain Morocco, occupying farmlands and woodlands. Though a common species, the study parameters were poorly studied in the area.
To date, it is known that the European serin is a residentbreeding species in Morocco and Algeria [11, 18], since this bird was recorded in forest areas and farmlands, mainly oases $[8,19]$. Similarly, in our case, nests of the European serin were found inside orchards and woodlands. However, the higher portion of nests was placed inside apple orchards 
TABle 4: Breeding success of the European Serin and failure factors at Moulouya high plain.

\begin{tabular}{|c|c|c|c|}
\hline \multicolumn{4}{|c|}{ Moulouya } \\
\hline Phase & Parameter & Number & $\%$ \\
\hline \multirow{5}{*}{ Nests } & Total & 65 & 100 \\
\hline & Succeeded & 48 & 73.84 \\
\hline & Predated & 5 & 7.69 \\
\hline & Deserted & 7 & 10.76 \\
\hline & Destructed & 5 & 7.69 \\
\hline \multirow{6}{*}{ Eggs } & Total & 167 & 100 \\
\hline & Succeeded & 146 & 87.42 \\
\hline & Predated & 8 & 4.79 \\
\hline & Deserted & 6 & 3.59 \\
\hline & Destructed & 2 & 1.19 \\
\hline & Unhatched & 5 & 2.99 \\
\hline \multirow{5}{*}{ Chicks } & Total & 146 & 100 \\
\hline & Succeeded & 137 & 93.83 \\
\hline & Predated & 5 & 3.42 \\
\hline & Died & 4 & 2.73 \\
\hline & Deserted & 0 & 0 \\
\hline
\end{tabular}

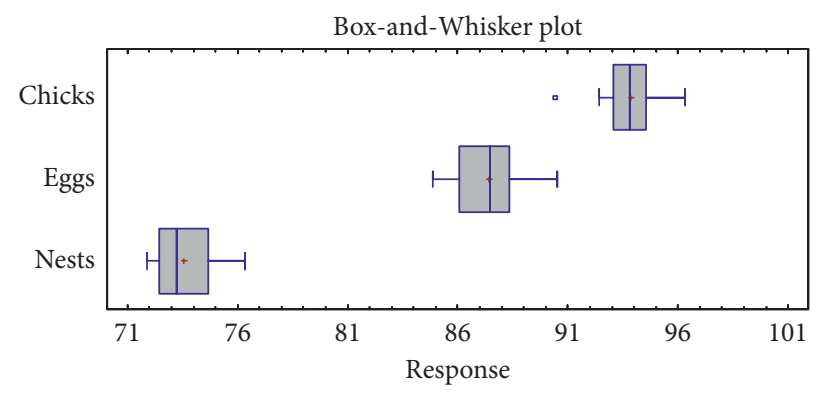

FIGURE 5: Comparison (graphical ANOVA) of reproductive success among breeding phases (nest construction, laying of eggs, and hatching of chicks) at Moulouya.

TABLE 5: Failure factors reducing the breeding success (success of chicks=emancipation of chicks, success of eggs = hatching of chicks, success of nests = occupied by the breeders) of the European serin.

\begin{tabular}{|c|c|c|c|c|c|}
\hline & & Estimate & Standard error & Wald test & $P$ \\
\hline \multirow{6}{*}{ Nest construction } & Intercept & -0.075 & 0.334 & 2.253 & 0.007 \\
\hline & Predation & -0.236 & 0.039 & 6.452 & 0.032 \\
\hline & Desertion & -1.043 & 0.057 & 9.765 & 0.004 \\
\hline & Destruction & -0.061 & 0.022 & 6.452 & 0.047 \\
\hline & Unhatched & -0.021 & 0.028 & 0.243 & 0.653 \\
\hline & Scale & 1.000 & 0.013 & & \\
\hline \multirow{6}{*}{ Hatching of eggs } & Intercept & -1.164 & 0.432 & 3.321 & 0.034 \\
\hline & Predation & -1.522 & 0.027 & 10.634 & 0.001 \\
\hline & Desertion & 0.037 & 0.042 & 6.876 & 0.030 \\
\hline & Destruction & -0.011 & 0.012 & 0.735 & 0.621 \\
\hline & Unhatched & -1.832 & 0.037 & 10.536 & 0.001 \\
\hline & Scale & 1.000 & 0.043 & & \\
\hline \multirow{5}{*}{ Emancipation of chicks } & Intercept & -1.232 & 0.154 & 2.136 & 0.034 \\
\hline & Predation & -2.417 & 0.014 & 9.342 & 0.022 \\
\hline & Desertion & -0.052 & 0.041 & 0.152 & 0.714 \\
\hline & Died & -1.062 & 0.003 & 10.016 & 0.026 \\
\hline & Scale & 1.000 & 0.043 & & \\
\hline
\end{tabular}

in comparison with woody habitats. The high incidence of Serin inside apple orchards (on Golden delicious and Starkrimson delicious) is related to their abundance in the study area [15, 20]. Additionally, [13] have reported the breeding of Serin in apple orchards in Midelt province. On the other hand, nests were cup-shaped, with small 
dimensions, and were placed at an important height above the ground to avoid ground stressors [21-23].

Breeding activities of the European serin started during the last week of April (construction of first nests) at Moulouya high plain and continued till the second week of July (the hatching of last chicks). Our results are similar to those cited in Europe, while they are different from those cited in North Africa. In Morocco (Marrakech, only $280 \mathrm{~km}$ to Moulouya) and in Algeria (Reghaïa in North), serin started breeding activities from February and March $[8,11]$, which is earlier by two months. On the contrary, in Europe, mainly France and Spain, the breeding activities of the serin were between April and May [7, 8, 24], and these are close to our results. However, the authors of $[15,16]$ have reported late breeding dates in other passerines, including the European turtle dove in the same area due to the effect of climatic conditions that delay breeding attempts in birds to avoid the vigorous climate in the area and its impact on broods $[15,16,25]$. To verify this issue, we have tested the effect of rainfall and temperatures on breeding periods (nest construction, laying of eggs, and hatching of chicks) and the obtained results did not show any relation between analysed parameters. Therefore, the analysis of other factors that could influence the selection of breeding dates is recommended. On the other side, in the end of the breeding season, two shorter broods were observed, which is in agreement with results recorded in the Algerian breeding population of the serin [9].

According to our annual breeding success estimates, the reproductive rate of serin at Moulouya high plain was higher during all breeding phases (construction of nests, laying of eggs, and rearing of chicks). Only a small clutch portion was failed due to predation (main reptiles such as Horseshoe snake Hemorrhoids Hippocrepis and Montpellier snake Malpolon monspessulanus), nest desertion (because of human disturbance via pesticide pulverization, which was done two times per month), and destruction of nests via the pression of the atomizers during pesticide application. In previous studies, factors causing loss of clutches or fail of breeding success were neglected due to the large population and distribution of the serin [26, 27]. In our study, we have unveiled the most threatening factors to serin breeding performances. Generally, farmland breeding birds are currently suffering from agricultural activities' intensification and new unsustainable methods [28]. Moreover, illegal wild birds' trade and captures cause a loss of avian diversity, mainly in North Africa [29].

\section{Conclusion}

Our findings highlight four key messages: (1) data indicate that serin selected farmland habitats for breeding in highaltitude zones; (2) breeding chronology was late in Moulouya high plain; (3) breeding success was higher in the studied zone; (4) predation, nest desertion, and destruction were the most threatening factors to European serin in Moulouya high plain. Given that European serin is widely distributed in the Mediterranean zone and western Palaearctic, more studies on the population size, foraging ecology, and population trends are needed to establish proper management strategies [30].

\section{Data Availability}

The data used to support the findings of this study are included within the article.

\section{Conflicts of Interest}

The authors declare they have no conflicts of interest.

\section{Acknowledgments}

The authors are grateful to their colleagues who helped in collecting data.

\section{References}

[1] A. Margalida, L. M. González, R. Sánchez et al., “A long-term large-scale study of the breeding biology of the Spanish imperial eagle (Aquila adalberti)," Journal of Ornithology, vol. 148, no. 3, pp. 309-322, 2007.

[2] T. Clutton-Brock and B. C. Sheldon, "Individuals and populations: the role of long-term, individual-based studies of animals in ecology and evolutionary biology," Trends in Ecology \& Evolution, vol. 25, no. 10, pp. 562-573, 2010.

[3] J. J. Green and C. J. A. Bradshaw, "The "capacity to reason" in conservation biology and policy: the southern elephant seal branding controversy," Journal for Nature Conservation, vol. 12, no. 1, pp. 25-39, 2004.

[4] P. G. Mota, "The functions of song in the serin," Ethology, vol. 105, no. 2, pp. 137-148, 1999.

[5] A. M. V. Leitão, Sexual selection: the Influence of Personality, Behavioural and Ornamental Traits in the Mate Choice of Serin (Serinus serinus), 2011.

[6] W. Fiedler, "Recent changes in migratory behaviour of birds: a compilation of field observations and ringing data," Avian Migration, pp. 21-38, 2003.

[7] J. C. Senar and J. L. Copete, "Survival and mean life span of the serin (Serinus serinus)," Bird Study, vol. 37, no. 1, pp. 40-43, 1990.

[8] S. Cramp and C. M. Perrins, "The Birds of the Western paleartic," Crows to Finches, Oxford University Press, Oxford, UK, 1994.

[9] S. Ouarab, M. Thévenot, and S. Doumandji, "Reproduction du Serin cini Serinus serinus (Linné, 1766) dans le parc d'El Harrach et aux abords du marais de Réghaïa, Algérie (Aves, Fringillidae)," Bulletin de 1'Institut Scientifique, Rabat, section Sciences de la Vie, vol. 29, pp. 53-61, 2007.

[10] D. Bendjoudi, H. Chenchouni, S. Doumandji, and J.-F. Voisin, "Bird species diversity of the mitidja plain (northern Algeria) with emphasis on the dynamics of invasive and expanding species," Acrocephalus, vol. 34, no. 156-157, pp. 13-26, 2013.

[11] D. Bergin, V. Nijman, and S. Atoussi, "Concerns about trade in wild finches in algeria," Oryx, vol. 53, no. 3, pp. 410-411, 2019.

[12] M. Thevenot, R. Vernon, and P. Bergier, The Birds of Morocco, British Ornithologists' Union, Peterborough, Canada, 2003.

[13] I. Mansouri, "The first survey of European serinchick's growth under natural conditions: which organs get maturity 
before nest leaving," Research Journal of Pharmaceutical Biological and Chemical Sciences, vol. 9, no. 5, pp. 64-73, 2018.

[14] J. Pretty and Z. P. Bharucha, "Sustainable intensification in agricultural systems," Annals of Botany, vol. 114, no. 8, pp. 1571-1596, 2014.

[15] J. Calladine, F. Buner, and N. J. Aebischer, "Temporal variations in the singing activity and the detection of turtle Doves Streptopelia turtur: implications for surveys," Bird Study, vol. 46, no. 1, pp. 74-80, 2010.

[16] P. J. Pietz and D. A. Granfors, "Identifying predators and fates of grassland passerine nests using miniature video cameras," The Journal of Wildlife Management, vol. 64, no. 1, pp. 71-87, 2000.

[17] I. Mansouri, D. Ousaaid, W. Squalli et al., "New data on migration time, breeding phenology, and breeding success of European turtle doves in their highest breeding habitats in North Africa," International Journal of Zoology, vol. 2021, Article ID e6629285, 8 pages, 2021.

[18] A. Nefla, R. Ouni, S. Selmi, and S. Nouira, "Breeding biology of a relictual Maghreb Magpie (Pica mauritanica) population in Tunisia," Avian Research, vol. 12, no. 1, 2021.

[19] D. Barreau and P. Bergier, "L'avifaune de la région de Marrakech (Haouz et Haut Atlas de Marrakech, Maroc). 3. Les espèces: Passereaux," Avifaune Région Marrakech Haouz Haut Atlas Marrakech Maroc 3 Espèces Passereaux, vol. 69, no. 2, pp. 261-309, 2001.

[20] A. Qninba, F. Cuzin, M. A. El-Agbani, and M. Thévenot, "Breeding avifauna of the jbel saghro (Anti-Atlas, Morocco), a detached mediterranean upland bordering the sahara, 30$31^{\circ} \mathrm{N} / 5-6^{\circ} \mathrm{W}, "$ Bulletin de l'Institut Scientifique, Section Sciences de la Vie, vol. 35, pp. 119-129, 2013.

[21] I. Mansouri, M. K. Al-Sadoon, M. Rochdi, B. A. Paray, M. Dakki, and L. Elghadraoui, "Diversity of feeding habitats and diet composition in the turtle doves Streptopelia turtur to buffer loss and modification of natural habitats during breeding season," Saudi Journal of Biological Sciences, vol. 26, no. 5, pp. 957-962, 2019.

[22] S. Selmi, "Determinants of distribution, abundance and reproductive success of the common blackbird (Turdus merula) in southern Tunisian oases," Ostrich, vol. 78, no. 2, pp. 309-313, 2007.

[23] A. Taberner, R. Tamarit, and J. A. Gil-Delgado, "Position of blackbird (Turdus merula) nests in orange trees," Avian Biology Research, vol. 5, no. 4, pp. 193-197, 2012.

[24] D. Wysocki, Ł. Jankowiak, J. L. Greño, A. Cichocka, I. Sondej, and B. Michalska, "Factors affecting nest size in a population of BlackbirdsTurdus merula," Bird Study, vol. 62, no. 2, pp. 208-216, 2015.

[25] D. Yeatman-Berthelot and G. Jarry, Nouvel Atlas Des Oiseaux Nicheurs de France, 1985-1989. Société Ornithologique de France, Société Ornithologique de France, Paris, France, 1995.

[26] I. Mansouri, W. Squalli, A. El Agy, A. El-Hassani, L. El Ghadraoui, and M. Dakki, "Comparison of nesting features and breeding success of turtle dove Streptopelia turtur between orchards and riparian habitats," International Journal of Zoology, vol. 2021, Article ID e5566398, 7 pages, 2021.

[27] M. J. Conroy, J. C. Senar, and J. Domènech, "Analysis of individual-and time-specific covariate effects on survival of Serinus serinus in North-Eastern Spain," Journal of Applied Statistics, vol. 29, no. 1-4, pp. 125-142, 2002.

[28] I. Mansouri, D. Ousaaid, W. Squalli, H. Sqalli, L. E. Ghadraoui, and M. Dakki, “The turtle dove (Streptopelia turtur) in midelt plain, Morocco: nesting preferences and breeding success versus the impact of predation and agricultural practices," Journal of Animal Behaviour and Biometeorology, vol. 8, no. 3, pp. 206-214, 2020.

[29] I. Razkallah, S. Atoussi, S. Telailia, M. Abdelghani, B. Zihad, and H. Moussa, "Illegal wild birds' trade in a street market in the region of Guelma, North-East of Algeria," Avian Biology Research, vol. 12, no. 3, pp. 96-102, 2019.

[30] E. Pagani-núñez and J. C. Senar, "Changes in carotenoidbased plumage colour in relation to age in European Serins Serinus serinus," Ibis, vol. 154, no. 1, pp. 155-160, 2012. 